\title{
Interactive comment on "Quality assurance and control on hydrological data off western Sardinia (2000-2004), western Mediterranean” by Alberto Ribotti et al.
}

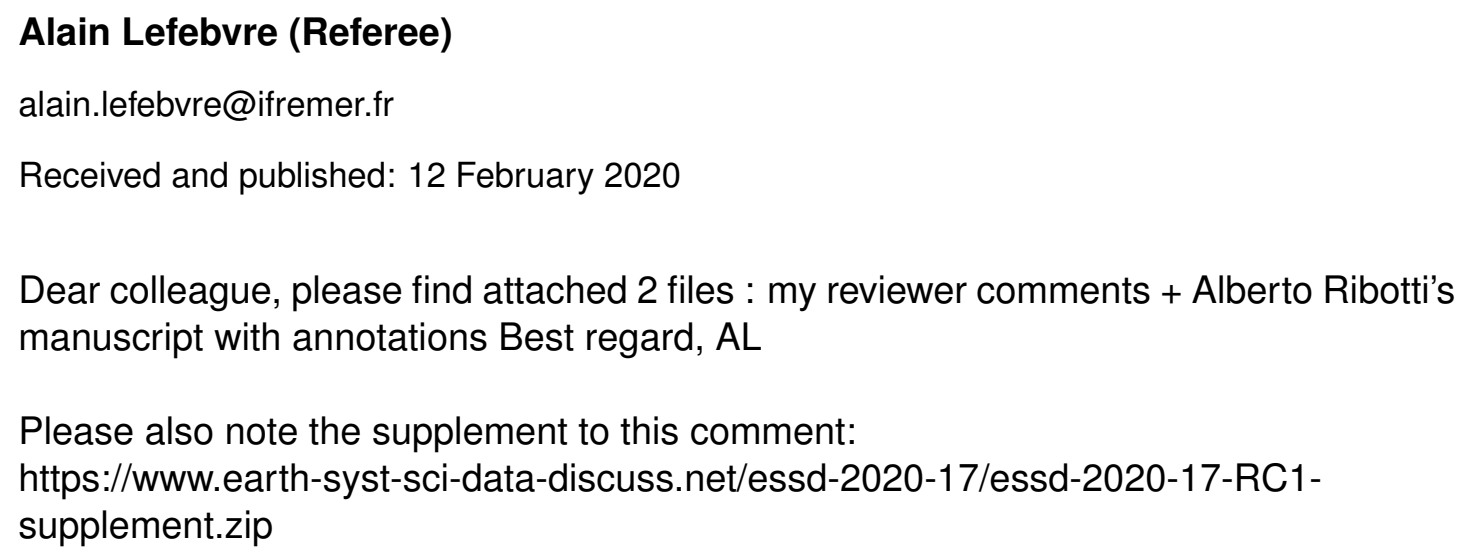

Dear colleague, please find attached 2 files : my reviewer comments + Alberto Ribotti's manuscript with annotations Best regard, $\mathrm{AL}$

Please also note the supplement to this comment: https://www.earth-syst-sci-data-discuss.net/essd-2020-17/essd-2020-17-RC1supplement.zip

Interactive comment on Earth Syst. Sci. Data Discuss., https://doi.org/10.5194/essd-2020-17, 2020. 